\title{
Validitas dan Kepraktisan Perangkat Pembelajaran IPA Terpadu Berbasis Software Adobe Flash Cs6 pada Tema Energi dan Makanan
}

\author{
${ }^{1}$ Luh Sukariasih, ${ }^{1 *}$ Syarifuddin, ${ }^{2}$ La Ode Nursalam, ${ }^{1}$ La Sahara \\ ${ }_{1}^{1}$ Program Studi Pendidikan Fisika, Universitas Halu Oleo, Sulawesi Tenggara \\ 2Program Studi Pendidikan Geografi, Universitas Halu Oleo, Sulawesi Tenggara
}

*Correspondence e-mail: 79syarifuddin@gmail.com

\begin{abstract}
Abstrak: Penelitian ini bertitik tolak adanya kesenjangan antara harapan pembelajaran dan hasil belajar fisika SMP, oleh sebab itu perlu diupayakan peningkatan mutu proses belajar mengajar melalui pengembangan perangkat pembelajaran yang sesuai dengan hakikat IPA dan standar kompetensi lulusan SMP. Penelitian ini bertujuan untuk mendeskripsikan kevalidan dan kepraktisan perangkat pembelajaran IPA terpadu berbasis software adobe flash CS6 pada materi energi dan makanan. Penelitian ini merupakan penelitian deskriptif evaluatif yang menghasilkan media pembelajaran IPA terpadu yang valid dan praktis untuk siswa SMP. Media pembelajaran yang dihasilkan divalidasi oleh 2 ahli pembelajaran dan 3 ahli media menggunakan lembar validasi. Kepraktisan produk ditentukan berdasarkan respon 2 guru dan 20 siswa terhadap media pembelajaran yang dikumpulkan menggunakan angket respon. Data hasil penelitian dianalisis secara deskriptif. Hasil penelitian menunjukkan media pembelajaaran dinyatakan valid, sedangkan respon yang diberikan guru dan siswa menunjukkan respon yang positif terhadap perangkat pembelajaran dan media pembelajaran yang dihasilkan. Berdasarkan temuan penelitian tersebut dapat disimpulkan bahwa perangkat pembelajaran IPA berbasis media software adobe flash CS6 yang dikembangkan valid dan praktis digunakan dalam pembelajaran IPA terpadu pada materi energi dan makanan bagi siswa SMP.
\end{abstract}

Kata kunci: kevalidan; kepraktisan; media pembelajaran

\section{Validity and Practicality of Integrated Science Learning Tools Based on Adobe Flash Cs6 Software on Energy and Food Themes}

\begin{abstract}
This research is based on the existence of a gap between learning expectations and learning outcomes for junior high school physics, therefore it is necessary to improve the quality of the teaching and learning process through the development of learning tools that are in accordance with the nature of science and competency standards for junior high school graduates. This study aims to describe the validity and practicality of integrated science learning tools based on Adobe Flash CS6 software on energy and food materials. This research is an evaluative descriptive research that produces an integrated science learning media that is valid and practical for junior high school students. The resulting learning media was validated by 2 learning experts and 3 media experts using a validation sheet. The practicality of the product is determined based on the responses of 2 teachers and 20 students to the learning media collected using a response questionnaire. The research data were analyzed descriptively. The results showed that the learning media was declared valid, while the responses given by the teacher and students showed a positive response to the learning tools and learning media produced. Based on the research findings, it can be concluded that the adobe flash CS6 software media-based science learning device that was developed is valid and practical to use in integrated science learning on energy and food materials for junior high school students.
\end{abstract}

Keywords: validity; practicality; instructional Media

How to Cite: Sukariasih, L., Syarifuddin, S., Nursalam, L. O., \& Sahara, L. (2020). Validitas dan Kepraktisan Perangkat Pembelajaran IPA Terpadu Berbasis Software Adobe Flash Cs6 pada Tema Energi dan Makanan. Empiricism Journal, 1(2), 96-101. https://doi.org/10.36312/ej.v1i2.250

https://doi.org/10.36312/ej.v1i2.250

Copyright $\odot 2020$, Sukariasih et al This is an open-access article under the CC-BY-SA License. (c) (i) (2)

\section{PENDAHULUAN}

IPA terpadu adalah sebuah pendekatan integratif yang mensintesis perspektif (sudut pandang/ tinjauan) semua bidang kajian dalam IPA untuk memecahkan permasalahan. Pendekatan pembelajaran terpadu merupakan salah satu implementasi kurikulum yang dianjurkan untuk diaplikasikan pada semua jenjang pendidikan, mulai dari tingkat Sekolah 
Dasar/Madrasah Ibtidaiyah (SD/MI). Sampai dengan Sekolah Menengah Atas/Madrasah Aliyah (SMA/MA). Pendekatan pembelajaran ini hakikatnya merupakan suatu pendekatan pembelajaran yang memungkinkan siswa baik secara individual maupun kelompok aktif mencari, menggali dan menemukan konsep serta prinsip secara holistik dan otentik .

Hakikat IPA meliputi empat unsur utama yaitu sikap, proses, produk dan aplikasi (Asy'ari dkk., 2019). Keempat unsur ini merupakan ciri IPA yang sebenarnya tidak dapat dipisahkan satu sama lain. Konsep IPA terpadu merupakan gabungan antara berbagai bidang kajian IPA yaitu fisika, kimia dan biologi, maka dalam pelaksanaannya tidak lagi terpisah-pisah melainkan satu kesatuan. Hal ini memberikan implikasi terhadap guru IPA agar menguasai IPA terpadu baik dari kajian fisika, kimia dan biologi agar proses belajar mengajar di kelas terlaksana secara efiktif dan efisien serta minat belajar siswa menjadi lebih tinggi sehingga berdampak positif terhadap hasil belajar siswa. Selain itu, dalam penyampaian IPA secara terpadu diperlukan suatu sarana yang berupa model pembelajaran beserta perangkat pembelajaran yang sesuai.

Proses pembelajaran lebih interaktif jika dalam pembelajaran tersebut terdapat sumber belajar yang dapat membantu guru untuk menarik perhatian siswa. Salah satu sumber belajar tersebut adalah media pembelajaran, namun tidak semua guru mengoptimalkan penggunaan media pembelajaran dalam proses belajar mengajar. Guru dituntut untuk mampu mengubah penyampaian materi agar menarik, memperbaiki pertanyaan guru yang sulit, mengatasi keterbatasan buku dan sumber belajar, serta melakukan pendekatan pada siswa (Istianah dkk., 2015).

Media sangat berperan penting di dalam proses pembelajaran, media merupakan suatu wahana penyalur pesan materi pelajaran yang disampaikan oleh seorang guru agar siswa dapat dengan mudah menerima pelajaran apa yang sudah disampaikan. Media yang baik adalah yang dapat memunculkan komunikasi dua arah atau interaktivitas (Liliasari dkk., 2016). Media pembelajaran adalah sebuah alat yang berfungsi untuk menyampaikan pesan pembelajaran. Penggunaan media pembelajaran secara tepat merupakan hal penting dalam proses pembelajaran, karena media mempunyai berbagai kelebihan antara lain membuat konsep yang abstrak dan kompleks menjadi sesuatu yang nyata, sederhana, sistematis dan jelas (Wulandari dkk., 2013).

Penggunaan media untuk membantu pembelajaran sudah mulai dirasakan manfaatnya, pengelolaan alat bantu pembelajaran sudah sangat dibutuhkan (Purwendri, 2013). Penggunaan media dapat membantu dalam pembelajaran karena keunggulan media dapat membantu siswa mempelajari bahan pelajaran yang luas, yang memuat berbagai konsep, fakta, prinsip, sikap dan keterampilan, dapat menumbuhkan motivasi belajar, sikap, dan cara belajar yang lebih efektif serta menumbuhkan persepsi yang lebih tinggi terhadap hal yang dipelajari, membantu siswa dan guru dalam proses instruksional media pembelajaran yang digunakan secara tepat mempunyai pengaruh yang cukup besar dalam pencapaian kompetensi/tujuan pebelajaran yang akan dicapai oleh guru saat proses belajar mengajar berlansung (Yanurizna, 2012).

Pengalaman lapangan peneliti menunjukkan bahwa sebagian besar siswa SMP menikmati suatu kegiatan pembelajaran apalagi menggunakan komputer dan bentuk multimedia lainnya. Hal ini sesuai dengan Permendiknas No 41 tahun 2007 pada uraian tentang rencana pelaksanaan pembelajaran yang menyebutkan bahwa proses pembelajaran untuk mencapai KD dilakukan dengan cara interaktif, inspiratif, menyenangkan, menantang, memotivasi siswa untuk berpartisipasi aktif serta memberikan ruang yang cukup bagi prakarsa, kreativitas dan kemandirian sesuai dengan bakat, minat dan perkembangan fisik serta psikologi siswa (Widayat dkk., 2014).

Komputer sebagai media pembelajaran mempunyai efektivitas yang cukup tinggi karena mampu menggabungkan dan menghadirkan teks, grafik, audio, gambar bergerak dengan menggabungkan link dan tool yang memungkinkan pemakai melakukan navigasi, berinteraksi dan berkreasi (Wulandari dkk., 2013). Salah satu aplikasi komputer yang menggabungkan konsep desain grafis dan audio visual adalah adode flash CS6. Adobe flash CS6 adalah software untuk menciptakan animasi dan konten multimedia. Desain yang interaktif yang hadir secara konsisten di seluruh desktop dan beberapa perangkat, termasuk tablet, smartphone, dan televisi. Berdasarkan uraian tersebut, penelitian ini bertujuan untuk mengevaluasi 
kevalidan dan kepraktisan perangkat pembelajaran berbasis media software adobe flash CS6 pada tema energi dan makanan untuk peserta didik SMP/MTS.

\section{METODE}

Penelitian ini merupakan penelitian deskriptif-evaluatif, yaitu penelitian yang menjelaskan/menggambarkan suatu gejala atau peristiwa, kejadian yang terjadi saat sekarang (Arikunto, 2006; Fraenkel et al., 2011) dan berusaha mendapatkan gambaran keadaan terkait validitas dan kepraktisan perangkat pembelajaran yang dikembangkan. Penelitian ini melibatkan 2 ahli pembelajaran dan 3 ahli media pada saat proses validasi perangkat pembelajaran, sedangkan pada saat pengukuran kepraktisan perangkat pembelajaran, 2 guru dan 20 siswa di SMPN 5 Kendari dilibatkan dalam memberikan respon terhadap perangkat pembelajaran yang dikembangkan.

Perangkat pembelajaran yang dikembangkan dalam penelitian ini berupa Rencana Pelaksanaan Pembelajaran (RPP), lembar Kerja Siswa (LKS), Buku Siswa pada tema energi dan makanan, dan Lembar Penilaian (LP). Tahap penelitian ini mengikuti tahap pengembangan model ADDIE (analyze, design, develop, and implement) (Seels \& Richey, 1994) seperti disajikan pada Gambar 1.

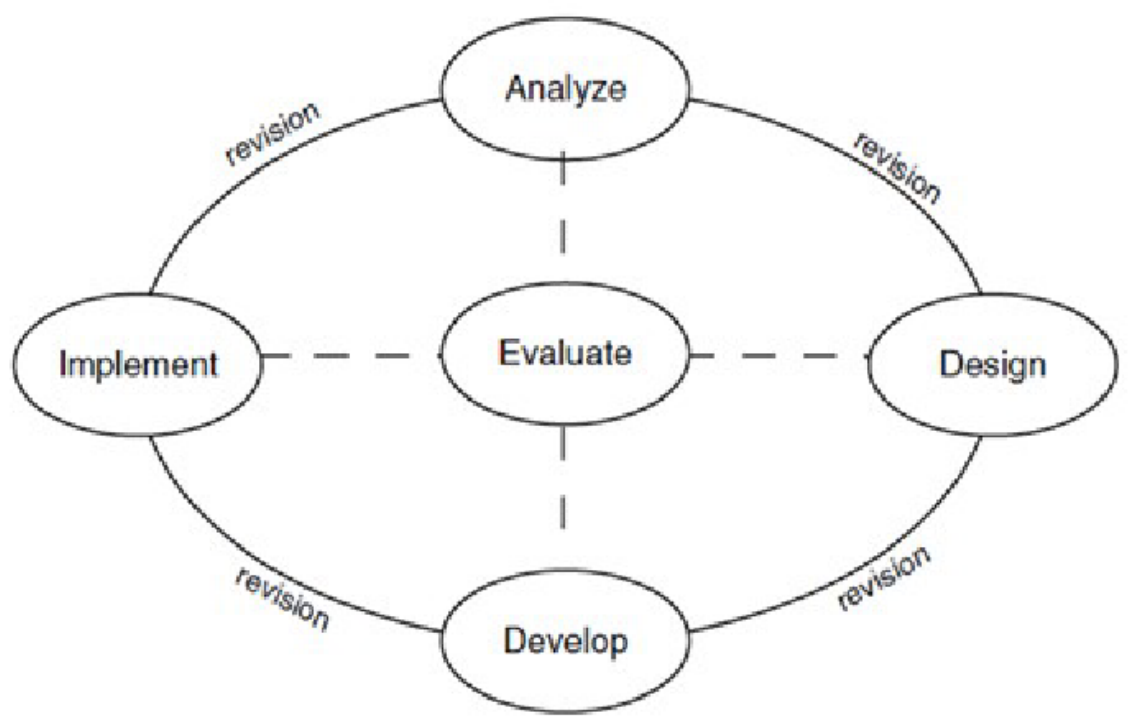

Gambar 1. Model pengembangan ADDIE

Perangkat pembelajaran yang dikembangkan divalidasi menggunakan instrument lembar valiadasi. Skor yang termuat pada lembar validasi perangkat pembelajaran menggunakan skala empat di mana skor $1=$ sangat tidak valid, $2=$ tidak valid, $3=$ valid, dan $4=$ sangat valid. Validator memberikan penilaiannya dengan memberikan tanda cek $(\sqrt{ })$ pada kolom skor yang telah tersedia. Rata-rata skor validasi perangkat pembelajaran yang dikembangkan ditentukan berdasarkan kriteria pada Tabel 1.

Tabel 1. Kriteria Perangkat Pembelajaran Berdasarkan Rata-rata skor Validator (Ratumanan \& Laurens, 2011)

\begin{tabular}{ll}
\multicolumn{1}{c}{ Interval Nilai } & \multicolumn{1}{c}{ Kriteria } \\
\hline$>3,6$ & Sangat Valid \\
$2,8-3,6$ & Valid \\
$1,9-2,7$ & Tidak Valid \\
$1,0-1,8$ & Sangat Tidak Valid \\
\hline
\end{tabular}

Data atau informasi mengenai respon guru dan siswa terhadap perangkat pembelajaran yang dikembangkan diproleh dengan mendistribusikan kuesioner. Guru dan siswa memberikan respon mengenai perangkat pembelajaran terkait kemudahan materi untuk dipahami, tampilan, dan kemudahan untuk digunakan. Kuisioner respon guru dan siswa terdiri 
atas 2 kategori yakni ya dan tidak. Secara matematis analisis respon guru dan siswa disajikan pada Persamaan 1.

$$
P=\frac{\sum K}{\sum N} x 100 \%
$$

Di mana $P$ : Persentase skor respon mahasiswa; $\sum K$ : Jumlah siswa yang memilih jawaban Ya atau Tidak; $\sum N$ : Jumlah siswa yang mengisi angket. Hasil analisis respon guru dan siswa selanjutnya dikategorisasikan berdasarkan Tabel 2.

Tabel 2. Kategori respon guru dan siswa (Riduwan, 2008)

\begin{tabular}{cc}
\hline Persentase (\%) & Kategori \\
\hline $0-20$ & Sangat lemah \\
$21-40$ & Lemah \\
$41-60$ & Cukup \\
$61-80$ & Kuat \\
$81-100$ & Sangat kuat \\
\hline
\end{tabular}

\section{HASIL DAN PEMBAHASAN}

Kevalidan perangkat pembelajaran berbasis media software adobe flash CS6 divalidasi oleh ahli pembelajaran dan media. Table 3 menunjukkan perangkat pembelajaran berbasis software adobe flash CS6 dinyatakan valid (rentang skor= 2,8-3,6) digunakan dalam pembelajaran sesuai dengan kriteria yang telah ditetapkan.

Tabel 3. Hasil validasi perangkat pembelajaran

\begin{tabular}{lcccc}
\hline \multirow{2}{*}{ Item } & \multicolumn{4}{c}{ Rerata } \\
\cline { 2 - 5 } & Ahli pembelajaran & Kriteria & Ahli media & Kriteria \\
\hline Rencana Pelaksanaan & 3.28 & Valid & 3.4 & Valid \\
Pembelajaran (RPP) & 3.5 & Valid & 3.332 & Valid \\
Lembar Kerja Siswa (LKS) & 3.3 & Valid & 3.668 & Sangat \\
Buku Siswa & 3.3 & Valid & 3.332 & valid \\
Lembar Penilaian (LP) & & & & Valid \\
\hline
\end{tabular}

Kepraktisan perangkat pembelajaran yang dikembangkan ditinjau berdasarkan respon guru dan siswa. Perangkat pembelajaran yang telah divalidasi dan direvisi berdasarkan saran validator selanjutnya di uji cobakan pada 2 guru dan 20 siswa SMP Negeri 5 Kendari untuk memberikan respon terhadap penyajian materi. Hasil respon guru dan siswa terhadap perangkat pembelajaran berbasis software adobe flash CS6 pada materi energi dan makanan yang dikembangkan secara singkat disajikan pada Tabel 4.

Tabel 4. Respon guru dan siswa

\begin{tabular}{lll}
\hline Item & Rerata (\%) & Kriteria \\
\hline Respon guru & 88,64 & Sangat kuat \\
Respon siswa & 86,6 & Sangat kuat \\
\hline
\end{tabular}

Pengembangan perangkat pembelajaran berbasis software adobe flash CS6 pada materi energi dan makanan telah melewati tahap pengembangan menggunakan model ADDIE, meliputi Analysis, Design, Development, Implementation, dan Evaluation. Tahap analysis (analisis) merupakan tahap dilakukannya analisis materi dan analisis tingkat kemampuan dan karakteristik sasaran pengguna. Perangkat pembelajaran yang dikembangkan juga didukung media pembelajaran dengan tipe file EXE dapat dibuka pada semua komputer atau PC (Personal Computer) tanpa bantuan software lain.

Tahap design (desain) dilakukan perancangan materi-materi yang disajikan dalam media, penyusunan naskah materi, penyusunan alur penyampaian materi dalam bentuk flowchart, pembuatan storyboard media serta pengumpulan bahan-bahan yang dibutuhkan dalam pengembangan media. Tahapan pembuatan selanjutnya adalah tahap development (pengembangan), pada tahap ini media pembelajaran dibuat sesuai dengan rancangan yang telah disusun pada kedua tahapan sebelumnya. Tahapan selanjutnya adalah tahapan implementation (implementasi), dalam tahap ini perangkat pembelajaran berbasis software 
adobe flash CS6 divalidasi oleh 2 ahli pembelajaran dan 3 ahli media dan diujicobakan kepada 2 guru dan 20 siswa SMP Negeri 5 Kendari untuk memberikan tanggapannya terhadap perangkat pembelajaran dan media yang dikembangkan. Hasil penelitian menunjukkan bahwa perangkat pembelajaran yang dikembangkan valid dan praktis digunakan dalam pembelajaran IPA terpadu pada materi energy dan makanan.

Dalam proses pembelajaran IPA dibutuhkan sumber belajar didukung perangkat pembelajaran sebagai pedoman guru dalam melaksanakan pembelajaran agar lebih terarah (Nur dkk., 2020). Perangkat pembelajaran yang dikembangkan dalam penelitian ini didukung media pembelajaran. Media pembelajaran dapat membantu siswa untuk tidak terpaku pada penjelasan guru dan membaca buku materi mengenai materi yang akan dipelajari (Maesarah dkk., 2020). Hasil penelitian menunjukkan bahwa penggunaan media pembelajaran dalam proses belajar dapat meningkatkan motivasi belajar siswa sehinnga berefek pada hasil belajar baik (Wulandari dkk., 2013). Sejalan dengan hasil penelitian tersebut, hasil penelitian lain menunjukkan penggunaan media pembelajaran dapat meningkatkan hasil belajar siswa (Widayat dkk., 2014). Perangkat pembelajaran yang dikembangkan didukung media pembelajaran IPA terpadu yang menggabungkan tiga bidang ilmu yaitu fisika, biologi dan kimia, keterkaitan antara konsep-konsep lain akan menambah kebermaknaan konsep yang dipelajari sehingga peserta didik mampu menerapkan perolehan belajarnya untuk memecahkan masalah-masalah nyata dalam kehidupan. Maka dari itu peneliti menyarankan untuk peneliti selanjutnya agar dapat menerapkan media pembelajaran yang telah dibuat kedalam proses belajar mengajar.

\section{KESIMPULAN}

Berdasarkan hasil yang telah diperoleh maka dapat ditarik kesimpulan bahwa pengembangan perangkat pembelajaran berbasis software adobe flash CS6 pada materi energi dan makanan valid dan praktis digunakan dalam pembelajaran IPA terpadu.

\section{REKOMENDASI}

Beberapa rekomendasi yang dapat disampaikan berdasarkan hasil penelitian ini adalah (1) penting untuk memperhatikan pembuatan animasi dalam media pembelajaran agat tidak berpotensi menimbukan miskonsepsi, dan (2) ujicoba perangkat pembelajaran yang dikembangkan perlu diimplementasikan dalam pembelajaran praktis di dalam kelas untuk menguji keefektifan perangkat yang telah dikembangkan.

\section{UCAPAN TERIMAKASIH}

Penelitian ini tidak menerima hibah khusus dari agensi pendanaan mana pun di sektor publik, komersial, atau nirlaba.

\section{DAFTAR PUSTAKA}

Asy'ari, M., Fitriani, H., Zubaidah, S., \& Mahanal, S. (2019). The Science Process Skills of Prospective Biology Teachers in Plant Cell Material Based on Gender. International Journal of Emerging Technologies in Learning (iJET), 14(19), 168. https://doi.org/10.3991/ijet.v14i19.11208

Istianah, I., Sudarmin, S., \& Wardani, S. (2015). Pengembangan media flashcard berpendekatan pramek tema energi pada makhluk hidup untuk siswa smp. Unnes Science Education Journal, 4(1), Article 1. https://doi.org/10.15294/usej.v4i1.4984

Liliasari, L., Supriyanti, S., \& Hana, M. N. (2016). Students' creative thinking enhancement using interactive multimedia of redox reaction. Jurnal Pengajaran MIPA, 21(1), 30-34. https://doi.org/10.18269/jpmipa.v21i1.36252

Maesarah, E. W., Sukri, A., \& Fitriani, H. (2020). Kelayakan LKS Berbasis Auditory Intellectually Repetition sebagai Bahan Ajar Alternatif Siswa. Empiricism Journal, 1(1), 12-19. https://doi.org/10.36312/ej.v1i1.261

Nur, A. R., Prayogi, S., Asy'ari, M., \& Muhali, M. (2020). Validitas perangkat pembelajaran berbasis pbl dengan pendekatan konflik kognitif untuk membelajarkan kemampuan metakognisi. Empiricism Journal, 1(1), 1-11. https://doi.org/10.36312/ej.v1i1.260 
Purwendri, R. (2013). Penggunaan media pembelajaran dengan program berbasislectora untuk meningkatkan minat dan hasil belajar ipakonsep gerak tropisme pada siswa smp kelas viii. Jurnal IImiah Guru Caraka Olah Pikir Edukatif, 0, Article 0. https://doi.org/10.21831/jig

Ratumanan, T. G., \& Laurens, T. (2011). Penilaian Hasil Belajar pada Tingkat Satuan Pendidikan. Unesa University Press.

Riduwan. (2008). Skala pengukuran variabel-variabel penelitian. Alfabeta. https://opac.perpusnas.go.id/DetailOpac.aspx?id=350661

Seels, B. B., \& Richey, R. C. (1994). Instructional Technology: The Definition and Domains of the Field. Information Age Publishing.

Widayat, W., Kasmui, K., \& Sukaesih, S. (2014). Pengembangan multimedia interaktif sebagai media pembelajaran ipa terpadu pada tema sistem gerak pada manusia. Unnes Science Education Journal, 3(2), Article 2. https://doi.org/10.15294/usej.v3i2.3353

Wulandari, F. R. A., Dewi, N. R., \& Akhlis, I. (2013). Pengembangan cd interaktif pembelajaran ipaterpadu tema energi dalam kehidupan untuk siswa smp. Unnes Science Education Journal, 2(2), Article 2. https://doi.org/10.15294/usej.v2i2.2033

Yanurizna, M. Y. (2012). Pengembangan media interaktif dengan tema sistem pencernaan manusia untuk smp kelas viii. PENSA: E-JURNAL PENDIDIKAN SAINS, 1(01), Article 01. https://ejournal.unesa.ac.id 